\title{
Mengenal Matematika dalam Perspektif Islam
}

\author{
Mualimul Huda \\ Sekolah Tinggi Agama Islam Negeri (STAIN) Kudus \\ hudamahbubi@gmail.com \\ Mutia \\ Sekolah Tinggi Agama Islam Negeri (STAIN) Curup \\ mutianasir24@gmail.com
}

\begin{abstract}
The science of Islam sourced from the Qur'an and Hadith should not be positioned in a place apart from other clusters of science, but should be put as a source of knowledge. The Qur'an and Hadith as the source of Islamic teachings serve as guidance (al-huda), explanation (at-tibyan), differentiator (al-furqan), and even healer (as-syifa'). There are many mathematical studies in the Qur'an that describe the science integrated in the Qur'an. One of the Qur'an explains about mathematical concepts such as set, line, calibrate, integer, fraction, and circle. Mathematics is a central science in everyday life and mathematics has been introduced early on. Mathematics is the language used in the creation of the universe. Thus, to learn and understand the verses of Kauniyyah is necessary mathematics. Understanding of the universe will lead to the awe of the power of Allah SWT. In addition, mathematics is also capable of providing a deeper approach to understanding Qawliyyah verses. Muslim scientists contribute thoughts and findings on mathematics. This proves that there is no dichotomy between science and religion.
\end{abstract}

Keywords: science, mathematics, Qur'an

Abstrak
Ilmu tentang Islam yang bersumber pada Alquran dan Hadits semestinya tidak
diposisikan pada tempat terpisah dari rumpun ilmu lainnya, melainkan seharusnya
diletakkan sebagai sumber ilmu. Alquran dan hadits sebagai sumber ajaran Islam
berfungsi sebagai petunjuk (al-huda), penjelas (at-tibyan), pembeda (al-furqan), dan
bahkan juga penyembuh penyakit (as-syifa'). Sungguh banyak kajian matematika yang
ada di dalam Alquran yang menjelaskan tentang ilmu pengetahuan yang terintegrasi
dalam Alquran. Salah satunya Alquran menjelaskan tentang konsep-konsep matematika
seperti himpunan, barisan, bilangan cacah, bilangan bulat, bilangan pecahan, dan
lingkaran. Matematika merupakan ilmu yang sentral dalam kehidupan sehari-hari dan
matematika sudah dikenalkan sejak dini. Matematika merupakan bahasa yang
digunakan dalam pencipataan alam semesta. Dengan demikian, untuk mempelajari dan
memahami ayat-ayat Kauniyyah tersebut diperlukan matematika. Pemahaman tentang
alam semesta akan bermuara pada ketakjuban akan kekuasaan Allah SWT. Selain itu,
matematika juga mampu memberikan pendekatan yang lebih dalam untuk memahami
ayat-ayat Qawliyyah. Ilmuwan muslim memberikan kontribusi pemikiran dan temuan

FOKUS : Jurnal Kajian Keislaman dan Kemasyarakatan vol. 2, no. 2, 2017

P3M Sekolah Tinggi Agama Islam Negeri (STAIN) Curup - Bengkulu

Available online: http://journal.staincurup.ac.id/index.php/JF

p-ISSN 2548-334X, e-ISSN 2548-3358 
mengenai matematika. Ini membuktikan bahwa tidak adanya dikotomi antara ilmu pengetahuan dan agama.

Kata Kunci: ilmu, matematika, al-Qur'an

\section{PENDAHULUAN}

Ilmu merupakan hal yang penting dalam kehidupan manusia. Banyak ayat-ayat Alquran dan hadits Nabi yang menganjurkan manusia untuk menuntut ilmu. Dalam Q.S. Al-Alaq (96) ayat $1-5$ Allah telah berfirman yang artinya "bacalah dengan (menyebut) nama Tuhanmu yang Menciptakan". Ayat tersebut memerintahkan kepada setiap umat manusia untuk membaca sebagai wahyu pertama yang diterima oleh Nabi Muhammad saw.

Dalam QS. Al-Ghasiyah (88) ayat 17-30 juga dijelaskan bahwa: "Tidakkah mereka perhatikan bagaimana unta diciptakan, langit ditinggikan, gunung ditegakkan dan bumi dihamparkan". Ayat-ayat tersebut jika diresapi maknanya secara mendalam, sebenarnya juga merupakan perintah dan anjuran menggali ilmu pengetahuan seluasluasnya dengan melakukan riset terhadap alam semesta.

Pengetahuan adalah suatu yang diketahui oleh manusia melalui pengalaman, informasi, perasaan atau melalui intuisi. Ilmu pengetahuan merupakan hasil pengolahan akal (berpikir) dan perasaan tentang sesuatu yang diketahui.

Sebagai makhluk berakal, manusia mengamati sesuatu. Hasil pengamatan itu diolah sehingga menjadi ilmu pengetahuan. Dengan ilmu pengetahuan itu dirumuskannya ilmu baru yang akan digunakannya dalam usaha memenuhi kebutuhan hidupnya dan menjangkau jauh di luar kemampuan fisiknya. ${ }^{1}$

Berbagai contoh peristiwa alam dan benda-benda yang ada di dunia ini, tidak dapat dipikirkan dan diolah oleh manusia untuk kepentingan hidupnya dan untuk memperkuat imannya, kecuali oleh orang yang berilmu yang menggunakan ilmunya. Allah berfirman:

"Dan perumpamaan-perumpamaan ini Kami buat untuk manusia; dan tiada yang memahaminya kecuali orang-orang yang berilmu" (Q.S Al-Ankabut : 43).

Nasr, sebagaimana dikutip Azra dkk, secara meyakinkan berpendapat bahwa ilmu pengetahuan dalam Islam berdasarkan pada ide kesatuan

${ }^{1}$ Nur Uhbiyati, Dasar-Dasar Ilmu Pendidikan Islam, (Semarang : PT Pustaka Rizki Putra, 2002), hlm. 3 
transeden yang merupakan jantung kewahyuan dalam Islam. Munculnya ilmu-ilmu dalam peradaban Islam dan perkembangan selanjutnya dapat dipahami tanpa spirit ada pada pewahyuan Islam dan pola pewahyuan ini telah membentuk pikiran, aksi, dan mengitari para ilmuwan dan peradaban Muslim bertanggung jawab pada penciptaan dan kultivasi sains. $^{2}$

Islam adalah agama yang membawa misi agar umatnya menyelenggarakan pendidikan dan pengajaran. Dasar pendidikan dalam Islam secara garis besar ada 3 yaitu: Alquran, sunnah, dan perundangundangan. ${ }^{3}$ Memposisikan Alquran dan sunnah sebagai grand concept atau grand theory mengandung arti bahwa keduanya berkedudukan sebagai sumber ajaran, baik sebagai sumber teologis maupun etis. Sebagai sumber, Alquran dan sunnah berisi konsep dasar yang melalui suatu proses sangat potensial bagi pengembangan dan pemberdayaan ilmu-ilmu islam. Alquran sesungguhnya menyediakan kemungkinan yang sangat besar untuk dijadikan sebagai cara berfikir atau metode memperoleh ilmu. ${ }^{4}$

Kitab suci yang diturunkan oleh Allah melalui Nabi Muhammad sesungguhnya sebagian besar membicarakan objek-objek sains seperti jagat raya (universe) dengan berbagai komponennya, kehidupan manusia dengan berbagai perilakunya dan juga mengenai jalan dan cara bagaimana agar hidup ini menempuh jalan keselamatan. ${ }^{5}$

Pada abad 21 ini yang dikenal sebagai abad teknologi dan informasi memiliki persepsi bahwa Alquran hanya menjelaskan tentang ilmu-ilmu agama dan sejarah islam saja, padahal realitanya Alquran adalah sumber dari segala hal mencakup teknologi, sains, ekonomi dan lain sebagainya. Ilmu pengetahuan di dunia ini dapat diklasifikasikan menjadi tiga golongan yaitu ilmu-ilmu alam (natural science), ilmu sosial (social science), dan ilmu-ilmu humaniora (humanities). Ilmu-ilmu alam yang bersifat murni terdiri atas ilmu fisika, ilmu kimia, dan ilmu biologi, dan sementara orang memasukkan lagi ilmu matematika. Ilmu-ilmu sosial yang masuk kategori ilmu murni meliputi ilmu sosiologi, antropologi,

${ }^{2}$ Azyumardi Azra, dkk., Strategi Pendidikan (Upaya Memahami Wahyu dan ilmu), (Yogyakarta : Pustaka Pelajar, 2010), hlm. 9

${ }^{3}$ Ibid., hlm. 4

${ }^{4}$ Fathul Mufid, "Integrasi Ilmu-Ilmu Islam", Jurnal Equilibrium, Vol. 1, No.01, 2013, diakses di journal.stainkudus.ac.id/index.php/equilibrium/article/download/200/ pdf pada tanggal 27 Desember 2017, hlm. 58.

${ }^{5}$ Azyumardi Azra, dkk., Op.cit., hlm. 49 
ilmu psikologi, dan ilmu sejarah. Sedangkan ilmu humaniora terdiri atas ilmu filsafat, bahasa dan sastra, serta seni.

Ketiga jenis ilmu-ilmu alam, ilmu sosial, dan humaniora itu berlaku secara universal, dimana saja. Hanya saja, kemudian di kalangan umat Islam merumuskan jenis ilmu tersendiri yang bersumberkan kepada Alquran dan sunnah. Beberapa ilmu dimaksud meliputi ilmu syariah, ilmu ushuluddin, ilmu tarbiyah, ilmu dakwah, dan ilmu adab yang selanjutnya disebut sebagai ilmu agama. Pembidangan seperti ini barangkali memerlukan tinjauan ulang secara seksama dan hati-hati sebab baik ilmu agama maupun ilmu umum memberikan manfaat yang besar bagi kehidupan. Apalagi akhir-akhir ini, ilmu umum lebih besar memberikan sumbangan pada kemajuan ilmu dan peradaban umat manusia daripada ilmu agama yang telah dikonstruk oleh umat Islam selama ini. ${ }^{6}$

Tampaknya tidak mudah ketika melihat kenyataan bahwa kebanyakan orang membangun persepsi bahwa antara ilmu dan agama menjadi satu kesatuan atau integratif, walaupun sesungguhnya hal itu tidak terlalu sulit jika kita berani merujuk kepada Alquran dan hadits secara langsung. Alquran dan Hadits Nabi memerintahkan mengembangkan ilmu pengetahuan dengan cara memikirkan ciptaan langit dan bumi, menyuruh untuk berpikir, mengamati, dan meneliti alam semesta. ${ }^{7}$

Ilmu tentang Islam yang bersumber pada Alquran dan sunnah semestinya tidak diposisikan pada tempat tersendiri terpisah dari rumpun ilmu lainnya, melainkan seharusnya diletakkan sebagai sumber ilmu. Alquran dan sunnah sebagai sumber ajaran Islam dalam kehidupan manusia merupakan petunjuk (al-huda), penjelas (at-tibyan), pembeda (al-furqan), dan bahkan juga penyembuh penyakit (as-syifa') semestinya diletakkan sebagai sumber ilmu pengetahuan. ${ }^{8}$

Alquran dan sunnah dalam pengembangan ilmu diposisikan sebagai sumber ayat-ayat qawliyyah sedangkan hasil observasi, eksperimen, dan penalaran logis diposisikan sebagai sumber ayat-ayat kauniyyah. Dengan posisinya seperti ini, maka berbagai cabang ilmu pengetahuan selalu dapat dicari sumbernya dari Alquran dan sunnah. Seperti, ilmu matematika yang dikembangkan atas dasar sumber Alquran dan sunnah serta hasil observasi, eksperimen, dan penalaran logis. Dalam Alquran,

\footnotetext{
${ }^{6}$ Ibid., hlm.50

${ }^{7}$ Fathul Mufid, Op.cit., hlm. 56.

${ }^{8}$ Azyumardi Azra, dkk., Op.cit., hlm.56
} 
misalnya disebutkan bahwa langit yang diciptakan Allah berjumlah tujuh. Penciptaan tujuh langit ini kalau dikolerasikan dengan peristiwa-peristiwa besar kenabian seperti turunnya wahyu dan isra'-mi'raj, ternyata memiliki rahasia matematis. Tidak hanya itu, masih banyak rahasia matematika lainnya yang tidak dapat dijelaskan semua dalam tulisan ini sehingga penulis hanya mengungkapkan beberapa konsep matematika dalam Islam yang berkaitan dengan Alquran.

Matematika merupakan ilmu yang sentral dalam kehidupan seharihari dan matematika sudah dikenalkan sejak dini. Begitu banyak kegiatan kita yang telah menggunakan matematika dalam kehidupan sehari-hari. Matematika memiliki pengaruh yang besar dalam kehidupan manusia. Disadari maupun tidak, sebenarnya seseorang tidak dapat terlepas dari matematika. Tetapi bagi sebagian besar orang menganggap bahwa matematika merupakan ilmu yang amat berat dan sulit.

Salah satu hal yang perlu dilakukan untuk mengintegrasikan matematika dengan Islam yaitu terlebih dahulu mengetahui apa itu matematika dan bagaimana sifatnya. Istilah matematika berasal dari kata Yunani, mathein atau manthenein yang berarti mempelajari. Kata ini memiliki hubungan yang erat dengan kata Sansekerta, medha atau widya yang memiliki arti kepandaian, ketahuan, atau intelegensia. ${ }^{9}$

Matematika adalah ilmu tentang besaran (kuantitas). Matematika adalah ilmu tentang hubungan (relasi). Matematika adalah ilmu tentang bentuk (abstrak). Matematika adalah ilmu yang bersifat deduktif. Matematika adalah ilmu tentang struktur-struktur yang logik. ${ }^{10}$ Definisidefinisi yang telah ada semuanya benar, berdasarkan sudut pandang tertentu. Beragamnya definisi itu dapat disebabkan oleh keluasan wilayah kajian matematika itu sendiri dan sudut pandang yang digunakan. Namun yang menjadi ciri khas matematika yang tidak dimiliki pengetahuan lain adalah matematika merupakan abstraksi dari dunia nyata, menggunakan bahasa simbol, dan menganut pola pikir deduktif. Untuk mempelajari matematika, selain mengetahui definisi matematika, akan lebih baik jika dikaji terlebih dahulu sifat-sifat atau karakteristik matematika itu sendiri.

Sifat atau karakteristik dari matematika terdiri dari objek matematika abstrak, memiliki simbol yang kosong dari arti, bertumpu pada

${ }^{9}$ Annisah Kurniati, "Mengenalkan Matematika Terintegrasi Islam kepada Anak Sejak Dini", Journal of Mathematics Education UIN Suska Riau, Vol.1, No.1, 2015, diakses di ejournal.uin-suska.ac.id pada tanggal 10 September 2017, hlm. 2.

${ }^{10}$ Abdusysyakir, Ada Matematika dalam Al-Qur'an, (Malang: UIN Malang Press, 2006), hlm. 2 
kesepakatan, berpola pikir deduktif, konsisten dalam sistemnya, dan memperhatikan semesta pembicaraannya. ${ }^{11}$ Keberadaan simbol ini memberi peluang yang besar kepada matematika untuk digunakan dalam berbagai ilmu dan kehidupan nyata. Seperti contoh simbol 1, 2, 3, 4, dan seterusnya tidak memiliki makna apa-apa, akan tetapi ide bilangan 1, 2, 3, dan seterusnya ada di alam ide seperti banyaknya benda yang dimiliki oleh seseorang berjumlah 2 dan sebagainya.

Mempelajari ilmu pengetahuan alam adalah bagian dari mempelajari agama sebab agama telah memerintahkannya. Ajaran Islam memerintahkan terhadap umatnya untuk menelaah alam semesta dalam rangka mendekatkan diri kepada Allah SWT demi tercapainya kebahagiaan di dunia dan akhirat. Begitu juga dengan matematika, seperti yang dikemukakan oleh Abdusysyakir dalam bukunya yang berjudul Ketika Kyai Mengajar Matematika, sesungguhnya matematika itu memiliki hubungan yang sangat erat dengan tradisi spiritual umat Islam, akrab dengan al-Qur'an, dan tentunya matematika juga dapat dijadikan sebagai "jalan" menuju pencapaian manfaat-kebahagiaan baik di dunia maupun akhirat.

\section{PEMBAHASAN}

\section{Peran Ilmuwan Muslim}

Fakta bahwa negara-negara Islam secara umum tertinggal dalam bidang sains memang merupakan ironi sejarah. Daftar panjang ilmuwan muslim tidak hanya berasal dari kawasan Arab. Mereka menulis karya mereka tidak hanya dalam ilmu agama (al-'ulum al-diniyyah), tetapi juga berbagai keilmuan yang rasional dan empiris.

Ilmuwan muslim dalam bidang matematika yang dikenal dengan matemamatikawan muslim sangat besar memberikan kontribusi pemikiran-pemikirannya dalam peradaban manusia khususnya kemajuan sains dan matematika. Upaya mereka melakukan universalitas keilmuan tidak bisa dipandang remeh bahkan tidak bisa dipandang sebelah mata, sekalipun oleh dunia barat.

Ilmu matematika itu sendiri pertama kali diperkenalkan oleh seorang ilmuwan Islam yaitu Al-Khawarizmi yang merupakan tokoh ilmuwan

11 Sumardyono. Karakteristik Matematika dan Implikasinya terhadap Pembelajaran Matematika, (Yogyakarta: Departemen Pendidikan Nasional Direktorat Jenderal Pendidikan Dasar dan Menengah Pusat Pengembangan Penataran Guru Matematika, 2004), hlm. 31. 
yang sangat konsen dalam pengembangan matematika. Ia banyak memberikan sumbangan pemikiran dalam bidang aljabar. Nama lengkap ilmuwan muslim ini adalah Abu Jafar Muhammad bin Musa AlKhawarizmi. Ia merupakan matematikawan pertama yang mengajarkan aljabar dengan elementer. Sangat menarik bahwa dalam mengembangkan aljabar, terdapat sesuatu yang sangat religius di dalam pemikiran Al-Khawarizmi, tidak hanya teori abstrak. Ia menulis buku tentang aljabar sebagai tanggapan dari permintaan Khalifah untuk menciptakan metode yang sederhana untuk membuat perhitungan berdasarkan prinsip Islam mengenai warisan, harta pusaka dan lainnya. Sehingga terciptalah aljabar yang menggunakan variabel-variabel. dalam bidang aljabar belum pernah ada metode yang bagus kecuali setelah al-Khawarizmi menulis bukunya yang berjudul al-Mukhtashar fi Hisab al-Jabr wa al-Muqabalah (buku kesimpulan proses kalkulasi untuk paksaan dan persamaan), namun sering disingkat dengan al-Jabar wa al-Muqabalah (aljabar dan persamaan).

Adapun karya besar al-Khawarizmi lainnya sebagai sumbangan yang cukup berarti bagi khasanah Islam dan pengembangan sains dan matematika adalah memperkenalkan desimal atau persepuluhan, konsep ini memperkaya khasanah dari penemuan formula seksagesimal atau perenampuluhan. Formula perenampuluhan merupakan perhitungan kuno yang diwariskan dari zaman Babilonia yang biasa digunakan dalam perhitungan jam yakni enam puluh detik, enam puluh menit. Sedangkan desimal banyak digunakan saat ini, sehingga angka dapat digunakan operasi angka di belakang koma, sebagai angka pecahan.

Selanjutnya, penggunaan variabel dan simbol-simbol. Hal ini mendorong pesatnya perkembangan formula-formula persamaan dalam matematika. Selain itu, al-Khawarizmi juga menemukan bilangan nol yang dapat mengubah kemajuan penemuan angka lewat angka romawi yang belum mengenal angka nol. ${ }^{12}$

Selain al-Khawarizmi, ada matematikawan muslim lainnya yang berperan dalam matematika yaitu Sayyidina Ali bin Abi Thalib karamallahu wajhah, dikenal sebagai pintunya ilmu (hadits Nabi : Ana Madinah al-ilmi wa Ali babuha: Aku adalah kota ilmu dan Ali adalah pintunya). Temuan Ali bin Abi Thalib adalah tentang bilangan kelipatan yang sekarang terkenal dengan istilah KPK (Kelipatan Persekutuan

12 Rizkon Halal Syah Aji, "Khazanah Sains dan Matematika dalam Islam", Salam:Jurnal Filsafat dan Budaya Hukum, Vol. 1, No.01, 2014, diakses di journal.uinjkt.ac.id pada tanggal 05 Agustus 2017, hlm. 166 - 167. 
Terkecil), berguna dalam operasi-operasi penjumlahan dan pengurangan pecahan, dengan cara menyamakan penyebutnya. Dalam hukum waris (faraidh) ini pun digunakan.

Berkaitan dengan persoalan waris, dikisahkan bahwa suatu waktu ada tiga orang menemui Ali bin Abi Thalib, mereka membawa persoalan waris yang rumit. Ketiga orang ini, mempunyai 17 ekor unta sebagai harta warisan. Mereka hendak membaginya dengan pembagian yang berbeda yakni $1 / 2,1 / 3$, dan $1 / 9$. Jika menggunakan perhitungan langsung masingmasing mendapat $81 / 2,52 / 3$, dan $18 / 9$., tentunya tidak mungkin dalam perhitungan unta yang dalam keadaan hidup. Ketika itu, Ali bin Abi Thalib menyarankan agar mereka menambahkan 1 ekor unta dengan cara meminjam kepadanya, sehingga jumlah unta sekarang menjadi 18 ekor. Walhasil mereka mendapatkan angka bulat yakni 18 ekor sehingga mudah dalam pembagian. Sehingga masing-masing mereka mendapatkan 9 ekor ( $1 / 2$ bagian), 6 ekor (1/3 bagian), dan 2 ekor (1/9 bagian). Sehingga total yang dibagikan tetap 17 sehingga satu ekor unta milik Ali bin Abi Thalib pun diambilnya kembali. Peristiwa ini menunjukkan bahwa kemampuan matematika Ali bin Abi Thalib ra sungguh luar biasa di masanya sehingga cepat tanggap menyelesaikan persoalan-persoalan sehari-hari dengan metode yang kreatif dan non konvensional. ${ }^{13}$

Seterusnya, kita tidak bisa melupakan Omar Khayyam, Nashiruddin Al-Thusi, dan Abu Ja'far Al-Khazin. Banyak sekali sebenarnya jika ingin kita sebutkan satu per satu nama ilmuwan muslim tersebut yang telah memberikan kontribusi yang sangat besar bagi perkembangan matematika. Hampir sebagian teori matematika dasar ditemukan dan dikembangkan oleh para ilmuwan Muslim sehingga bisa berkembang seperti sekarang ini.

Ilmuwan muslim memeriksa alam dan mengembangkan ilmu, sesuai dengan perintah Allah SWT. Mereka akan sampai pada kebenaran, karena antara ayat-ayat Tuhan di alam semesta yang berada di dalam Alquran tak saling bertentangan. Ilmu pengetahuan sebenarnya justru dapat digunakan untuk mempertebal iman atau keyakinan. Sementara agama sebaliknya, ia dapat memberikan bimbingan di mana akal manusia tidak dapat mencapainya. Disinilah pentingnya integrasi ilmu pengetahuan dan agama.

\section{Integrasi Matematika dan Islam}

\footnotetext{
${ }^{13}$ Ibid., hlm. 166
} 
Sauri dalam Ahmad Wachidul Kohar yang dikutip oleh Nihayati memaknai bahwa integrasi sebagai proses memadukan nilai-nilai tertentu terhadap sebuah konsep lain sehingga menjadi satu kesatuan yang koheren dan tidak bisa dipisahkan atau proses pembauran hingga menjadi satu kesatuan yang utuh dan bulat. ${ }^{14}$ Dalam konteks ini, maka akan dipadukan materi matematika dengan ayat Alquran sebagai sumber pengetahuan tertinggi dalam pendidikan Islam sehingga menjadi perpaduan antara ilmu matematika dan agama.

Kuntowijoyo dalam Fathul Mufid menyatakan bahwa inti dari integrasi ilmu adalah upaya menyatukan (bukan sekedar menggabungkan) wahyu Tuhan dan temuan pikiran manusia (ilmu-ilmu rasional), tidak mengucilkan Tuhan (sekularisme) atau mengucilkan manusia (other wordly asceticisme). Model integrasi ini adalah menjadikan Alquran dan Sunnah sebagai grand theory pengetahuan. Sehingga ayat-ayat Kauniyyah dan Qawliyyah dapat dipakai. Integrasi yang dimaksud di sini adalah berkaitan dengan usaha memadukan keilmuan umum dengan Islam tanpa harus menghilangkan keunikan-keunikan antara dua keilmuan tersebut. ${ }^{15}$

Dalam Alquran, banyak ditemukan ayat yang menjelaskan konsep matematika diantaranya yang dibahas dalam kajian ini adalah tentang himpunan, barisan, bilangan cacah, bilangan bulat, bilangan pecahan, dan lingkaran. Adapun Fathul Mufid juga menambahkan bahwa Alquran juga menyinggung tentang pengetahuan angka-angka dalam Q.S. Al-Kahfi (18): 11-12 dan ayat 9, perkalian dan perhitungan bilangan dalam Q.S. Maryam (19) : 84 dan ayat $94-95 .^{16}$

\section{Ayat-ayat Alquran tentang Himpunan}

Himpunan merupakan kumpulan objek-objek yang berbeda. Objek yang terdapat di dalam himpunan disebut elemen, unsur, atau anggota. ${ }^{17}$ Sedangkan Abdusyakir menyebutkan himpunan (set) sebagai kumpulan atau koleksi objek-objek yang terdefinisi dengan jelas (well-defined) ${ }^{18}$

14 Nihayati, "Integrasi Nilai-Nilai Islam dengan Materi Himpunan (Kajian Terhadap Ayat-Ayat Alquran)", Jurnal Edumath, Vol. 3 No.01, 2017, diakses di ejournal.stkippringsewu-lpg.ac.id pada tanggal 05 November 2017, hlm. 67.

${ }^{15}$ Fathul Mufid, Op.cit., hlm. 68.

${ }^{16}$ Ibid., hlm.59-60.

${ }^{17}$ Rinaldi Munir, Matematika Diskrit, (Bandung : Informatika Bandung, 2012), hlm. 48

18 Abdusysyakir, Matematika 1 Kajian Integratif Matematika dan Alquran, (Malang: UIN Malang Press, 2009), hlm. 5 
Makna "terdefinisi dengan jelas" adalah tidak bersifat relatif, objek yang dimaksud harus jelas dan dapat diberikan contoh anggotanya.

Berdasarkan penelitian Nihayati (2017) mengenai himpunan tersebut, maka ayat-ayat Alquran yang menggambarkan tentang himpunan dapat ditemukan pada surat Al-An'am ayat 128 dan Surat Al-Waqi'ah ayat 7$10 .^{19}$

Dalam surat Al-An'am ayat 128, Allah berfirman yang artinya :

"dan (ingatlah) hari diwaktu Allah menghimpunkan mereka semuanya (dan Allah berfirman): "Hai golongan jin, Sesungguhnya kamu telah banyak menyesatkan manusia", lalu berkatalah kawankawan meraka dari golongan manusia: "Ya Tuhan kami, sesungguhnya sebahagian daripada kami telah dapat kesenangan dari sebahagian (yang lain) dan kami telah sampai kepada waktu yang telah Engkau tentukan bagi kami". Allah berfirman: "Neraka itulah tempat diam kamu, sedang kamu kekal di dalamnya, kecuali kalau Allah menghendaki (yang lain)". Sesungguhnya Tuhanmu maha bijaksana lagi maha mengetahui." (Q.S Al-An'am : 128).

Diagram Venn yang digambarkan dalam ayat di atas adalah dua himpunan yang lepas karena tidak memiliki irisan $(\cap)$. Kedua himpunan tersebut masuk pada hal makhluk yang diciptakan Allah yaitu golongan jin (makhluk gaib) dan golongan manusia.

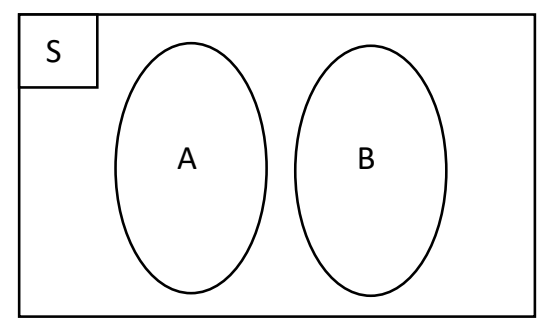

$\mathrm{S}=$ makhluk ciptaan Allah

$\mathrm{A}=$ golongan jin

$\mathrm{B}=$ golongan manusia

Selanjutnya, adalah Surat Al-Waqi'ah ayat 7-10. Allah berfirman yang artinya :

"dan kamu menjadi tiga golongan. Yaitu golongan kanan. Alangkah mulianya golongan kanan itu. Dan golongan kiri. Alangkah sengsaranya golongan kiri itu. Dan orang-orang yang beriman paling dahulu." (Q.S Al-Waqi'ah : 7-10).

${ }^{19}$ Nihayati, Op.,cit., hlm. 70 - 71 


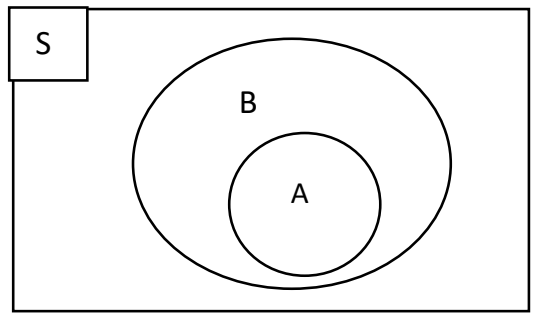

$\mathrm{S}=$ manusia

$\mathrm{A}=$ Nabi dan umatnya yang

beriman

$\mathrm{B}=$ golongan kanan

Diagram Venn yang digambarkan dalam ayat di atas adalah A (golongan Nabi dan umatnya yang beriman) merupakan subhimpunan dari B (golongan kanan), maka gabungan A dan B merupakan himpunan $\mathrm{B}$ yaitu golongan kanan. Dalam matematika dituliskan sebagai $\mathrm{A} \subset \mathrm{B}$, maka $\mathrm{A} \cup \mathrm{B}=\mathrm{B}$.

Adapun ayat-ayat Alquran lainnya yang berkenaan dengan himpunan antara lain : Surat Al-Baqarah ayat 97, Surat Al-Hujurat ayat 13, Surat Taha ayat 6, Surat Az-Zumar ayat 9, dan Surat Lukman ayat 20.

\section{Ayat-ayat Alquran tentang Barisan}

Barisan (sequence) merupakan susunan bilangan-bilangan yang dibentuk menurut suatu urutan tertentu. Bilangan-bilangan yang tersusun tersebut disebut suku. Dalam surat As-Shaff ayat 1, Allah berfirman yang artinya:

"telah bertasbih kepada Allah apa saja yang ada di langit dan apa saja yang ada di bumi; dan Dia-lah yang Maha Perkasa lagi Maha Bijaksana." (Q.S As-Shaff : 1).

Selanjutnya, ditemukan juga dalam surat Ash Shaff ayat 4, Allah berfirman :

"Sesungguhnya Allah menyukai orang yang berperang dijalanNya dalam barisan yang teratur seakan-akan mereka seperti suatu bangunan yang tersusun kokoh.” (Q.S As-Shaff : 4)

Kedua ayat di atas menjelaskan kesamaan konsep yaitu mengenai barisan yang padat.

Sebagai contoh pada barisan real $\mathrm{X}=\frac{1}{n}$ adalah barisan yang konvergen ke nol. Pemeriksaan kekonvergenan barisan tersebut bisa diperiksa dengan definisi barisan konvergen, konvergen Cauchy, konvergen seragam, dan konvergen Lipshit. Contoh barisan yang kokoh adalah barisan Nabi Muhammad SAW ketika memenangkan Islam pada 
zaman Jahiliyah. Untuk memeriksa kekokohan barisan ini bisa dilihat bagaimana Rasulullah SAW mengatur umatnya dalam sejarah perjuangan Islam $^{20}$.

Dalam Surat Al-Mulk ayat 3, Allah juga berfirman bahwa :

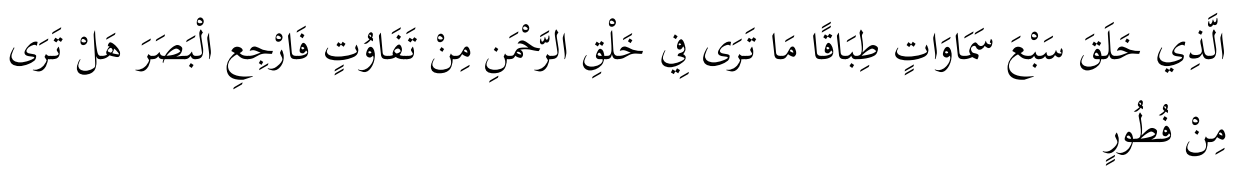

Artinya: "yang telah menciptakan tujuh langit berlapis-lapis. kamu sekali-kali tidak melihat pada ciptaan Tuhan yang Maha Pemurah sesuatu yang tidak seimbang. Maka lihatlah berulang-ulang, Adakah kamu Lihat sesuatu yang tidak seimbang?" (Q.S Al-Mulk : 3).

Ayat di atas menjelaskan tentang lapisan langit yang mengikuti barisan bilangan real $(\mathrm{R})$ yaitu suatu fungsi yang terdefinisi pada bilangan asli $\mathrm{N}=\{1,2,3, \ldots\}$ dengan range termuat pada himpunan $\mathrm{R}$.

\section{Ayat-ayat Alquran tentang Bilangan Cacah dan Bilangan Bulat}

$$
\text { وَلَيَالِ عَشْرِ وَالشَفْعِع وَالْوَتْرِ }
$$

Artinya : "dan malam yang sepuluh dan yang genap dan yang ganjil." (Q.S Al-Fajr : 2-3).

Malam yang sepuluh itu ialah malam sepuluh terakhir dari bulan Ramadhan dan ada pula yang mengatakan sepuluh yang pertama dari bulan Muharram Termasuk di dalamnya hari Asyura. Ada pula yang mengatakan bahwa malam sepuluh itu ialah sepuluh malam pertama bulan Zulhijjah.

Ayat di atas menjelaskan tentang bilangan cacah yaitu bilangan yang terdiri dari nol dan bilangan asli. Sepuluh malam terakhir yang dijelaskan pada bulan Ramadhan tersebut menunjukkan bilangan-bilangan pada matematika khususnya bilangan cacah. Sedangkan untuk bilangan bulat dijelaskan Allah dalam surat Al-Isra ayat: 12.

${ }^{20}$ Deden Suparman, "Hitungan (Matematika) dalam Perspektif Alquran", Jurnal ISTEK, Vol. 7, No.02, 2013, diakses di journal.uinsgd.ac.id pada tanggal 15 Juli 2017, hlm. 13-14. 
Artinya : "dan Kami jadikan malam dan siang sebagai dua tanda, lalu Kami hapuskan tanda malam dan Kami jadikan tanda siang itu terang, agar kamu mencari kurnia dari Tuhanmu, dan supaya kamu mengetahui bilangan tahun-tahun dan perhitungan. dan segala sesuatu telah Kami terangkan dengan jelas." (Q.S. Al-Isra : 12)

Tanda malam dan tanda siang menunjukkan tanda positif dan tanda negatif pada garis bilangan. Bilangan bulat merupakan bilangan yang terdiri bilangan negatif, nol, dan positif. Jika ada sebuah bilangan bulat positif 2 diberi tanda negatif, maka akan menjadi bilangan negatif -2 , dan sebaliknya, jika negatif dihilangkan maka akan kembali menjadi bilangan bulat positif. Begitulah keadaan siang dan malam, selalu bergantian.

\section{Ayat-ayat Alquran tentang Bilangan Pecahan}

Dalam surat An-Nisa ayat 11, 12, dan 176 Allah berfirman yang artinya :

"[11]. Allah mensyari'atkan bagimu tentang (pembagian pusaka untuk) anak-anakmu. Yaitu : bahagian seorang anak lelaki sama dengan bahagian dua orang anak perempuan; dan jika anak itu semuanya perempuan lebih dari dua, Maka bagi mereka dua pertiga dari harta yang ditinggalkan; jika anak perempuan itu seorang saja, Maka ia memperoleh separo harta. Dan untuk dua orang ibu-bapa, bagi masing-masingnya seperenam dari harta yang ditinggalkan, jika yang meninggal itu mempunyai anak; jika orang yang meninggal tidak mempunyai anak dan ia diwarisi oleh ibu-bapanya (saja), Maka ibunya mendapat sepertiga; jika yang meninggal itu mempunyai beberapa saudara, Maka ibunya mendapat seperenam. (Pembagianpembagian tersebut di atas) sesudah dipenuhi wasiat yang ia buat atau (dan) sesudah dibayar hutangnya. (Tentang) orang tuamu dan anak-anakmu, kamu tidak mengetahui siapa di antara mereka yang lebih dekat (banyak) manfaatnya bagimu. Ini adalah ketetapan dari Allah. Sesungguhnya Allah Maha mengetahui lagi Maha Bijaksana. [12]. Dan bagimu (suami-suami) seperdua dari harta yang ditinggalkan oleh isteri-isterimu, jika mereka tidak mempunyai anak. jika isteri-isterimu itu mempunyai anak, maka kamu mendapat seperempat dari harta yang ditinggalkannya sesudah dipenuhi wasiat yang mereka buat atau (dan) sesudah dibayar hutangnya. Para isteri 
memperoleh seperempat harta yang kamu tinggalkan jika kamu tidak mempunyai anak. Jika kamu mempunyai anak, maka para isteri memperoleh seperdelapan dari harta yang kamu tinggalkan sesudah dipenuhi wasiat yang kamu buat atau (dan) sesudah dibayar hutanghutangmu. Jika seseorang mati, baik laki-laki maupun perempuan yang tidak meninggalkan ayah dan tidak meninggalkan anak, tetapi mempunyai seorang saudara laki-laki (seibu saja) atau seorang saudara perempuan (seibu saja), maka bagi masing-masing dari kedua jenis saudara itu seperenam harta. Tetapi jika saudara-saudara seibu itu lebih dari seorang, maka mereka bersekutu dalam yang sepertiga itu, sesudah dipenuhi wasiat yang dibuat olehnya atau sesudah dibayar hutangnya dengan tidak memberi mudharat (kepada ahli waris). (Allah menetapkan yang demikian itu sebagai) syari'at yang benar-benar dari Allah, dan Allah Maha mengetahui lagi Maha Penyantun." (Q.S. An-Nisa : 11 - 12).

Dahulu, Allah sudah mensyariatkan kepada manusia akan pembagian harta waris (faraidh) menggunakan konsep matematika yaitu pecahan. Masalah faraidh adalah masalah yang berkenaan dengan pengaturan dan pembagian harta warisan bagi ahli waris menurut bagian yang ditentukan dalam Alquran. Untuk pembagian harta warisan perlu diketahui lebih dahulu berapa jumlah semua harta warisan yang ditinggalkan, berapa jumlah ahli waris yang berhak menerima, dan berapa bagian yang berhak diterima ahli waris. Ayat di atas telah menjelaskan ketentuan bagi yang berhak diterima oleh ahli waris yang disebut dengan Furudhul Muqaddarah.

Untuk dapat memahami dan dapat melaksanakan masalah faraidh tersebut dengan baik, maka harus memahami terlebih dahulu konsep matematika yang berkaitan dengan bilangan pecahan, pecahan senilai, konsep keterbagian, Faktor Persekutuan Terbesar (FPB), Kelipatan Persekutuan Terkecil (KPK), dan konsep pengukuran yang meliputi volume, luas, dan berat sehingga akan memudahkan memahami masalah Faraidh. Ayat di atas telah menyebutkan bilangan-bilangan pecahan yang digunakan dalam perhitungan harta warisan seperti 1/3, 1/6, 1/4, dan sebagainya. Begitu juga dulu ketika Ali bin Abi Thalib saat membagi harta warisan tiga orang yang memiliki 17 unta menggunakan konsep KPK. 
Selain An-Nisa ayat $11-12$, Allah SWT juga menjelaskan masalah faraidh tersebut dalam ayat 176 berikut dan Allah SWT berfirman yang artinya :

"mereka meminta fatwa kepadamu (tentang kalalah). Katakanlah: "Allah memberi fatwa kepadamu tentang kalalah (yaitu): jika seorang meninggal dunia, dan ia tidak mempunyai anak dan mempunyai saudara perempuan, Maka bagi saudaranya yang perempuan itu seperdua dari harta yang ditinggalkannya, dan saudaranya yang laki-laki mempusakai (seluruh harta saudara perempuan), jika ia tidak mempunyai anak; tetapi jika saudara perempuan itu dua orang, Maka bagi keduanya dua pertiga dari harta yang ditinggalkan oleh yang meninggal. dan jika mereka (ahli waris itu terdiri dari) saudara-saudara laki dan perempuan, Maka bahagian seorang saudara laki-laki sebanyak bahagian dua orang saudara perempuan. Allah menerangkan (hukum ini) kepadamu, supaya kamu tidak sesat. dan Allah Maha mengetahui segala sesuatu." (Q.S. An-Nisa : 176).

\section{Ayat-ayat Alquran tentang Lingkaran}

Dalam Surat Al Hajj ayat 29 Allah SWT berfirman:

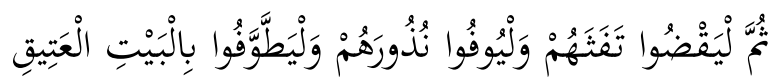

Artinya : "Kemudian, hendaklah mereka menghilangkan kotoran yang ada pada badan mereka dan hendaklah mereka menyempurnakan nazar-nazar mereka dan hendaklah mereka melakukan melakukan thawaf sekeliling rumah yang tua itu (Baitullah).” (Q.S. Al Hajj : 29).

Ayat di atas menjelaskan kepada manusia tentang hubungan thawaf dengan ka'bah. Thawaf merupakan salah satu rukun haji yaitu mengelilingi ka'bah. Sebagaimana yang kita ketahui bahwa thawaf adalah berjalan keliling yang membentuk lingkaran dan dilakukan sebanyak tujuh kali.

Pada hadits yang lain Rasulullah SAW bersabda : "Bahwasannya Nabi Muhammad SAW, tatkala sampai Mekkah telah mendekatkan ke Hajar Aswad, kemudian beliau sapu Hajar Aswad itu dengan tangan beliau, kemudian beliau berjalan ke sebelah kanan beliau, berjalan cepat tiga kali berkeliling dan berjalan biasa empat kali berkeliling”. (HR. Muslim dan Nasai).

Dari Abu Hurairah, bahwasannya ia telah mendengar Nabi SAW bersabda: 
"Barang siapa berkeliling ka'bah tujuh kali dan ia tidak berkata selain dari : Maha Suci Allah dan Segala Puji bagi Allah, tidak ada Tuhan yang patut disembah kecuali Allah, Allah Maha Besar dan tidak ada daya upaya dan kekuatan kecuali dengan pertolongan Allah. Orang yang membaca kalimat tersebut, dihapuskan dari padanya sepuluh kejahatannya, dan dituliskan sepuluh kebaikan dan diangkat derajatnya sepuluh tingkat". (HR. Ibnu Majah).

Di dalam rumus luas atau keliling lingkaran selalu digunakan alat ukur yang disebut phi yang besarnya 22/7 $=3,14$.

Angka 22 dan 7 memiliki korelasi dengan ibadah haji dan rukun thawaf. Surat yang artinya haji adalah surat ke 22 yaitu Al-Hajj. Thawaf membentuk lingkaran sebanyak tujuh kali. Ini merupakan kombinasi angka 22 dan 7 yang sama dengan phi lingkaran. ${ }^{21}$

Sungguh banyak kajian matematika yang ada di dalam Alquran yang menjelaskan tentang ilmu pengetahuan yang terintegrasi dalam Alquran. Tidak ada ciptaan Allah SWT yang sia-sia untuk diciptakan, termasuk matematika. bahkan matematika merupakan bahasa yang digunakan dalam pencipataan alam semesta. Dengan demikian, untuk mempelajari dan memahami ayat-ayat Kauniyyah tersebut diperlukan matematika. pemahaman tentang alam semesta akan bermuara pada ketakjuban akan kekuasaan Allah SWT. Selain itu, matematika juga mampu memberikan pendekatan yang lebih dalam untuk memahami ayat-ayat Qawliyyah.

\section{PENUTUP}

Ilmu pengetahuan merupakan hasil pengolahan akal (berpikir) dan perasaan tentang sesuatu yang diketahui itu. Berbagai contoh peristiwa alam dan benda-benda yang ada di dunia ini, tidak dapat dipikirkan dan diolah oleh manusia untuk kepentingan hidupnya dan untuk memperkuat imannya, kecuali oleh orang yang berilmu yang menggunakan ilmunya. Pada abad 21 ini yang dikenal sebagai abad teknologi dan informasi memiliki persepsi bahwa Alquran hanya menjelaskan tentang ilmu-ilmu agama dan sejarah islam saja, padahal realitanya Alquran adalah sumber dari segala hal mencakup teknologi, sains, ekonomi dan lain sebagainya. Alquran diturunkan kepada manusia sebagai pembeda antara yang hak

\footnotetext{
at

Darmawanari, "Islam

dan Matematika"

diakses

di www.darmawanari.wordpress.com pada tanggal 7 Desember 2017
} 
dan batil, juga menuntun manusia untuk menuntut dan mengembangkan ilmu pengetahuan. Ilmu tentang Islam yang bersumber pada Alquran dan Hadits semestinya tidak diposisikan pada tempat tersendiri terpisah dari rumpun ilmu lainnya, melainkan seharusnya diletakkan sebagai sumber ilmu. Alquran dan hadits dalam pengembangan ilmu diposisikan sebagai sumber ayat-ayat qawliyyah sedangkan hasil observasi, eksperimen, dan penalaran logis diposisikan sebagai sumber ayat-ayat kauniyyah. Dengan posisinya seperti ini, maka berbagai cabang ilmu pengetahuan selalu dapat dicari sumbernya dari Alquran dan hadits. Seperti, ilmu matematika yang dikembangkan atas dasar sumber Alquran dan hadits serta hasil observasi, eksperimen, dan penalaran logis. Matematika itu sendiri memiliki hubungan yang sangat erat dengan tradisi spiritual umat Islam, akrab dengan al-Qur'an, dan tentunya matematika juga dapat dijadikan sebagai "jalan" menuju pencapaian manfaat-kebahagiaan baik di dunia maupun akhirat. Dalam Alquran, banyak ditemukan ayat yang menjelaskan konsep matematika diantaranya adalah tentang himpunan, barisan, bilangan cacah, bilangan bulat, bilangan pecahan, dan lingkaran.

\section{DAFTAR PUSTAKA}

Abdusysyakir. 2006. Ada Matematika dalam Al-Qur'an. Malang: UIN Malang Press.

Abdusysyakir. 2009. Matematika 1 Kajian Integratif Matematika dan Alquran. Malang: UIN Malang Press.

Annisah Kurniati, "Mengenalkan Matematika Terintegrasi Islam kepada Anak Sejak Dini", Journal of Mathematics Education UIN Suska Riau, Vol.1, No.1, 2015, diakses di ejournal.uin-suska.ac.id pada tanggal 10 September 2017.

Azra, Azyumardi, dkk. 2010. Strategi Pendidikan (Upaya Memahami Wahyu dan ilmu). Yogyakarta: Pustaka Pelajar.

Deden Suparman, "Hitungan (Matematika) dalam Perspektif Alquran", Jurnal ISTEK, Vol. 7, No.02, 2013, diakses di journal.uinsgd.ac.id pada tanggal 15 Juli 2017.

Fathul Mufid, "Integrasi Ilmu-Ilmu Islam", Jurnal Equilibrium, Vol. 1, No.01, 2013, diakses di journal.stainkudus.ac.id/index.php/ equilibrium/article/download/200/pdf pada tanggal 27 Desember 2017.

Nihayati, "Integrasi Nilai-Nilai Islam dengan Materi Himpunan (Kajian Terhadap Ayat-Ayat Alquran)", Jurnal Edumath, Vol. 3 No.01, 2017, 
diakses di ejournal.stkippringsewu-lpg.ac.id pada tanggal 05 November 2017.

Sumardyono. 2004. Karakteristik Matematika dan Implikasinya terhadap Pembelajaran Matematika. Yogyakarta: Departemen Pendidikan Nasional Direktorat Jenderal Pendidikan Dasar dan Menengah Pusat Pengembangan Penataran Guru Matematika.

Rinaldi Munir. 2012. Matematika Diskrit. Bandung: Informatika Bandung.

Rizkon Halal Syah Aji. "Khazanah Sains dan Matematika dalam Islam", Salam:Jurnal Filsafat dan Budaya Hukum, Vol. 1, No.01, 2014, diakses di journal.uinjkt.ac.id pada tanggal 05 Agustus 2017.

Uhbiyati, Nur. 2002. Dasar-Dasar Ilmu Pendidikan Islam. Semarang: PT Pustaka Rizki Putra.

Darmawanari, "Islam dan Matematika" diakses di www.darmawanari.wordpress.com pada tanggal 7 Desember 2017

Karina Kusuma. "Matematika dalam Islam". Diakses di www. Kompasiana.com. pada tanggal 5 Desember 2017. 